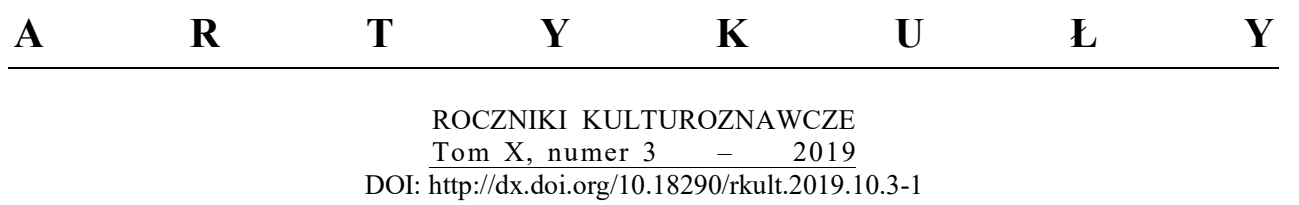

JUSTYNA SZULICH-KAŁUŻA

\title{
DYSKURS O WIELOKULTUROWOŚCI LUBLINA W LOKALNEJ PRASIE
}

\author{
WSTĘP
}

Problematyka wielokulturowości jawi się obecnie w innym kontekście niż kilka lat wcześniej. Z uwagi na procesy globalizacji, nasilające się kontakty międzynarodowe i międzykulturowe, wielokulturowość, którą najogólniej zdefiniować można jako pluralizm kultur, języków, ideologii, norm, wartości, religii, stała się powszechnym doświadczeniem współczesności. Wyzwaniem stojącym przed instytucjami medialnymi jest ukazywanie procesów interkulturowych w duchu różnorodności kulturowej, poszanowania i tolerancji grup mniejszościowych. Ich zasadniczą rolą jest informowanie, negocjowanie treści ${ }^{1}$, edukowanie i przygotowanie społeczeństw do wielokulturowości. Zasadniczym celem podjętym $\mathrm{w}$ artykule jest charakterystyka medialnego dyskursu o wielokulturowości w mediach lokalnych - jego istoty, założeń teoretycznych i pełnionych funkcji. Dyskurs w paradygmacie konstruktywistycznym uznaję za rozbudowany zespół norm: językowych, kulturowych, społecznych; wzorów zachowań werbalnych i niewerbalnych; schematów oraz różnorodnych form narracyjnych, deskryptywnych, perswazyjnych lub aksjologicznych ${ }^{2}$.

Dr hab. Justyna Szulich-KaŁuŻa, prof. KUL - kierownik Katedry Komunikacji Wizualnej, dyrektor Instytutu Dziennikarstwa i Zarządzania, Wydział Nauk Społecznych Katolickiego Uniwersytetu Lubelskiego Jana Pawła II; Al. Racławickie 14, 20-950 Lublin, e-mail: justyna.szulichkaluza@kul.pl; ORCID: https://orcid.org/0000-0002-6845-168X.

${ }^{1} \mathrm{Na}$ istotną rolę mediów w negocjowaniu treści kulturowych zwraca uwagę: Jerzy MiKUŁOwSKI-POMORSKI, „Współczesny problem kulturowości i wielokulturowości w komunikowaniu”, w Multikulturalizm w sferze mediów, red. Magdalena Ratajczak (Wrocław: Wydawnictwo UWr, 2007), 18.

2 Janina LABOCHA, Tekst, wypowiedź, dyskurs w procesie komunikacji językowej (Kraków: Wydawnictwo UJ, 2008), 78. 
Zasadniczy problem towarzyszący przedmiotowym refleksjom dotyczy pytania, czy dyskurs medialny o wielokulturowości przyczynia się do jakościowych, pozytywnych zmian w sferze społecznej, ekonomicznej i lokalno-środowiskowej, a w konsekwencji do budowania społeczeństw opartych na humanistycznych wartościach w pełni demokratycznych. Poszukam odpowiedzi na pytanie: czy w tym dyskursie pojęcia pluralizmu, otwartości, odmienności, spotkania, zrozumienia, współpracy, współdziałania, dialogu informacyjnego i negocjacyjnego tworzą gęstą siatkę teoretycznych założeń we współczesnych społeczeństwach wielokulturowych ${ }^{3}$. W szczególności interesują mnie dwa zagadnienia: środki językowe używane w tworzeniu dyskursu oraz uszczegółowione egzemplifikacje tematycznych i znaczeniowych kategorii definiujących wielokulturowość Lublina w dyskursie prasy lokalnej. Zakładam, że językowe odtwarzanie rzeczywistości za pomocą narzędzi i nośników medialnych należy do istotnych funkcji mediów w społeczeństwie.

Kreacja rzeczywistości za pomocą środków językowych obejmuje kilka podstawowych poziomów:

- strukturalizację świata - wyodrębnienie obiektów i zjawisk będących obiektem zainteresowania;

- opis, charakterystykę wyodrębnionych obiektów;

- uporządkowanie opisanych obiektów i zjawisk;

- ocenę opisanych obiektów i zjawisk;

- ubogacenie emocjonalne - wniesienie sposobu doświadczania, przeżywania i wyobrażania otaczającej rzeczywistości ${ }^{4}$.

Dyskurs prasowy definiuję jako typ autorskiego dyskursu tekstowego, przeznaczonego dla czytelników zarówno rzeczywistych, jak i potencjalnych, w którym zawarta jest jakaś intencja nadawczo-odbiorcza. Cechy tekstów, potraktowanych jako jednostki komunikacyjne, pozwalają na doprecyzowanie, że każdy tekst jest samodzielną całością informacyjną, posiadającą znaczenie. Czytanie tekstu, jeżeli założymy, że towarzyszy temu rozumienie jego znaczenia, wprowadza ten tekst $\mathrm{w}$ dyskurs. Jest to więc swego rodzaju ożywianie tekstu, polegające na wprowadzaniu go ponownie w sytuację komunikacyjną, tym razem odbioru. Wcześniejszą sytuacją komunikacyjną była aktualizacja dyskursu w momencie pisania tekstu .

\footnotetext{
${ }^{3}$ Marek REMBIERZ, „Otwarcie edukacji międzykulturowej na krytyczną recepcję pedagogicznego przesłania religii w kontekście pluralizmu światopoglądowego”, Spoleczeństwo. Studia, prace badawcze i dokumenty z zakresu nauki społecznej Kościoła nr 3(142)(2018): 46.

${ }^{4}$ Jolanta MAĆKIEWICZ, „Wyspa - językowy obraz wycinka rzeczywistości”, w Językowy obraz świata, red. Jerzy Bartmiński (Lublin: Wydawnictwo UMCS, 1999), 193-206.

${ }^{5}$ Szerzej o dyskursie prasowym: Justyna SzULICH-KAŁUŻA, Projekty tożsamościowe rodziny upowszechniane w polskich tygodnikach opiniotwórczych (Lublin: Wydawnictwo KUL, 2013), 114-117.
} 
Materiał badawczy wykorzystany w części empirycznej opracowania tworzy 24 artykuły prasowe lokalnych tytułów, które łączy data ukazania się - po 2000 r. Internetowe wydania dzienników Kurier Lubelski (liczba wyselekcjonowanych artykułów do analizy - 5) i Dziennik Wschodni (9) oraz bezpłatnych tygodników lubelskich: Nowy Tydzień (5) i Nasze Miasto (5) potraktowałam jako źródło tekstów kulturowych o językowej sile kreującej rzeczywistość społeczną. Szczegółową techniką wykorzystaną w opracowaniu jest analiza zawartości i analiza pól semantycznych. Pozwoli ona na odtworzenie struktury pól semantycznych wokół pojęcia wielokulturowy Lublin, które obejmuje listę wyrażeń i zwrotów powiązanych z omawianym pojęciem w tekstach prasowych.

\section{WIELOKULTUROWOŚĆ - TEORIE, POSTULATY I TERMINOLOGIA BADAWCZA}

Wielokulturowość jest jednym z częściej używanych pojęć we współczesnych dyskursach naukowych w wielu kontekstach. Odnosi się zarówno do zjawisk narodowościowych, jak i określonych doświadczeń społecznych. Reprezentuje teoretyczne podejście dobrze wpisujące się w nurt postmodernistyczny, podkreślając współistnienie różnych kultur i ich równość. Zgodnie z tezami postmodernizmu - nie ma kultury lepszej ani gorszej, są one po prostu różne i jednakowo ważne. Żaden typ dyskursu, żadna wizja świata, ideologia, religia, specjalny zespół zjawisk kulturowych nie mogą rościć sobie prawa do wyróżnionej pozycji, a tym bardziej do dyktowania ludziom reguł poznawania świata i postępowania, dlatego powinna być zachowana pełna tolerancja każdej odmienności, pełne poszanowanie „innego”, afirmacja różnorodności i rozproszenia ${ }^{6}$. Zwolennicy wielokulturowości podkreślają jej humanistyczny rdzeń, jej korelację z szacunkiem i uznaniem ludzkiej godności osób ze wszystkich grup kulturowych. Przeciwnicy twierdzą, że działa jak siła dzieląca, która stwarza niebezpieczeństwo podważenia jedności narodowej

\footnotetext{
${ }^{6}$ Szerzej: Wolfgang Welsch, Nasza postmodernistyczna moderna, thum. Roman Kubicki, Anna Zeidler-Janiszewska, (Warszawa: Oficyna Naukowa, 1998); Terry EAGLETon, Iluzje postmoderniz$m u$, thum. Piotr Rymarczyk (Warszawa: Wydawnictwo Spacja 1998); Jean-Francois LyOTARD, „Beantwortung der Frage: Was ist postmodern?”, w TENŻE, Postmoderne für Kinder. Briefwechsel aus den Jahren 1982-1985 (Wiedeń: Passagen Verlag, 1987), 11-31.

${ }^{7}$ Antonina KoLODII, ,The Idea and Diverse Reality of Multiculturalism: Are They Applicable to Newly Independent States?", Political Studies, https://political-studies.com/?p=734\&lang=en (dostęp: 10.09.2019).
} 
Zjawisko wielokulturowości występowało w dziejach ludzkości od zawsze. Pierwsze jego przejawy dostrzegamy już w starożytnym Egipcie i Rzymie, chociaż wówczas nie podlegały one naukowej refleksji - ówczesne mieszanie się kultur stanowiło zazwyczaj rezultat wojen, dyplomacji bądź ówczesnych ruchów ludności ${ }^{8}$. Obecnie pojęcie wielokulturowości przeżywa spektakularny renesans, zwłaszcza w naukach społecznych i humanistycznych. Wysiłki formułowania teoretycznych modeli zjawiska przypadają na lata 60. i początek lat 70. XX wieku równolegle w Kanadzie, Australii i USA. Jedną z pierwszych definicji wielokulturowości sformułował w 1975 r. Jean Burnet, określając ją jako politykę wspierania wieloetniczności w instytucjach narodowych kultury angielskiej i francuskiej ${ }^{9}$. Kanadyjska ustawa o wielokulturowości z 1988 r. nałożyła na rząd obowiązek ochrony wszystkich osób, zapewnienia ich równego uczestnictwa w życiu społecznym, równego traktowania i równej ochrony prawnej ,przy jednoczesnym poszanowaniu i docenieniu ich różnorodności”10.

W USA idea wielokulturowości zakorzeniona jest w społecznej i intelektualnej atmosferze ruchów na rzecz praw obywatelskich w latach 60 . XX wieku. Była szeroko stosowana w kontekście reformy programu nauczania w szkołach publicznych, która rozpoczęła się na początku lat 80 . XX wieku. Reforma miała na celu wyeliminowanie swoistego eurocentrycznego nastawienia w edukacji i zapewnienie bardziej „zróżnicowanego” kulturowo programu nauczania. Od późnych lat 80 . w amerykańskich publikacjach społecznych miała miejsce wielokulturowa eksplozja ${ }^{11}$. Równocześnie zjawisko to uznano za odpowiedź na porażkę koncepcji asymilacyjnych: anglokonformizmu (one nation, one flag and one language), tygla (melting pot) i pluralizmu kulturowego, chociaż to właśnie pluralizm jest najczęściej uznawany za ideologię konstytuującą współczesną rzeczywistość USA. W latach 80. i 90. XX wieku

\footnotetext{
${ }^{8}$ Anna ŚLIZ i Marek Stanisław SzCZEPAŃSKI, „Wielokulturowość i jej socjologiczny sens. Festival Caravan czy Wielokulturowe Street Party?”, Studia Socjologiczne nr 4(203)(2011): 7-8.

9 Jean BuRNET, „Multiculturalism, Immigration and Racism”, Canadian Ethnic Studies 7, nr 1 (1975): 35-39, cyt za: Will KyMLICKA, Multicultural Citizenship: A Liberal Theory of Minority Rights (Oxford: Clarendon Press, 1995), 17.

${ }^{10}$ Ustawa głosiła m.in. że „wielokulturowość [...] uznaje wolność wszystkich członków kanadyjskiego społeczeństwa do zachowania, wzbogacania i dzielenia się dziedzictwem kulturowym”, zob. Antonina KolODII, „The Idea and Diverse Reality of Multiculturalism” (dostęp: 10.09.2019).

${ }^{11}$ Nathan Glazer ujawnił, że w 1988 r. nie było odniesienia do tego terminu w bazie danych Nexis, w 1989 r. było tylko 33 referencje, ale w 1991 r. ponad 600, w 1993 r. - 1200, w 1994 r. - 1500, zob. Nathan Glazer, We Are All Multiculturalists Now (Cambridge (MA): Harvard University Press, 1997), 7-8.
} 
pojęcie wielokulturowości znalazło ważne miejsce w przestrzeni krajów Europy Zachodniej ${ }^{12}$.

Pozornie łatwy do zdefiniowania termin „wielokulturowość” najczęściej bywa określany jako współegzystencja wielu kultur, języków, religii, ideologii, systemów normatywnych, aksjologicznych i moralnych w obrębie określonej przestrzeni społecznej. W takim ujęciu chodzi o dystrybutywne rozumienie kultury, czyli przede wszystkim o kultury narodowe i etniczne, z których każda jest układem wzorów zachowań (idei, wartości, norm, zasad) oraz ich wytworów - tworzonych, nabywanych, stosowanych i przekształcanych w procesie życia społecznego ${ }^{13}$.

Dokonując przeglądu teoretycznych ujęć definicyjnych wielokulturowości, warto przywołać intelektualny dorobek Leona Dyczewskiego, dla którego wielokulturowość jako zjawisko i określona sytuacja były przedmiotem starannej uwagi i refleksji. Powyższa kategoria pojęciowa znalazła swe umocowanie w licznych publikacjach naukowych jego autorstwa, a także w inicjatywach promujących myśl o pozytywnych relacjach z innym oraz odmiennymi kulturami. Jedną z nich był np. pomysł stworzenia Centrum Dialogu Międzykulturowego w Łodzi. Według Dyczewskiego wielokulturowość to zinstytucjonalizowane na zasadach demokratycznych współżycie w obrębie organizmu państwowego jednostek, wspólnot i innych form zbiorowości. Autor dostrzegał, że we współczesnym świecie wielokulturowość staje się zjawiskiem coraz bardziej powszechnym, chociaż nie przez wszystkich uznawanym, a wręcz coraz mniej akceptowalnym. Wielokulturowość z jednej struny sprzyja kształtowaniu postaw tolerancji i poszanowania odmienności, $\mathrm{z}$ drugiej strony prowadzi do pojawiania się niebezpiecznych zjawisk izolacjonizmu, gettoizacji, a także dyskryminacji. Zbliżone do ideału społeczeństwo wielokulturowe ,[...] nie dzieli się na różnorodne, istniejące obok siebie, niepowiązane kawałki, lecz jest różnorodną całością, jednością w wielości, a tym samym bogatym w treść i formę, wieloczynnikowym środowiskiem rozwoju dla swoich członków”" ${ }^{14}$. Dalej w pracach Dyczewskiego przeczytamy: „Europa powinna być jedna, ale różnorodna. Jedność nie oznacza bowiem jednolitości. Europa powinna jednoczyć ludzi żyjących w swoich kulturach. Jednostki, które obcują z odmiennymi kulturami, mogą kształtować autonomię własnej osoby. Zyskują niezależność od środowiska, w którym przyszło mu funkcjonować.

\footnotetext{
${ }^{12}$ ŚLIZ, SzCZEPAŃSKI, „Wielokulturowość i jej socjologiczny sens”, 8.

${ }^{13}$ Marian GolKA, Socjologia kultury (Warszawa: Scholar, 2007), 55-59.

${ }^{14}$ Leon DycZewSKI, Kultura $w$ calościowym planie rozwoju (Warszawa: Instytut Wydawniczy Pax, 2011), 32.
} 
Dostrzegając korzyści wynikające z wielokulturowości, nie można jej jednak przeceniać. W stosunku do jednostek i społeczeństwa pozostaje bowiem ona zawsze wartością instrumentalną" ${ }^{15}$. Różnorodność kulturowa jest interesująca, bowiem w niej przejawia się potencjalność natury ludzkiej i twórczość konkretnych ludzi oraz całych społeczeństw. „Poznawanie i przeżywanie różnych kultur jest ważnym czynnikiem rozwoju naszej osobowości, pomaga nam w uświadomieniu i przeżywaniu własnej tożsamości społeczno-kulturowej, w jej ocenianiu i ściślejszym jeszcze wiązaniu się z nią"16. Wielokulturowość nie może także oznaczać relatywizmu kulturowego, czyli sytuacji, w której w niewłaściwej poprawności imigranci przebywający w Europie mogą kultywować swoje wartości w niezmienionej formie, a społeczeństwa przyjmujące muszą ten stan zaakceptować, niezależnie, czy wydaje się to im właściwe, czy też nie. Leon Dyczewski wymieniał kilka pozytywnych stron przenikania kultur z podkreśleniem, że powinny dotyczyć one obu stron międzykulturowego kontaktu. Po pierwsze, jednostki poprzez takie kontakty zmuszane są do poznawania odmiennych wartości, norm, wzorów zachowań, zwyczajów, form estetycznych, przedmiotów, a następnie do dokonywania ciągłych wyborów - jak napisał „muszą nauczyć się żyć z odmiennością"17. Po drugie, różnorodna rzeczywistość kulturowa sprzyja kształtowaniu zdolności łączenia różnorodnych elementów w nowe całości i utrzymywania ładu w różnorodności, czyni ludzi zdolnymi do przeciwstawiania się ujednoliconym gustom i przekraczania przeciętności ${ }^{18}$.

Na potrzeby niniejszego opracowania wskażę na kilka punktów istotnych dla kategorii wykorzystanych w analizie własnej artykułów prasowych.

Zakładam po pierwsze, że wielokulturowość to nie tylko współistnienie kultur obok siebie, ale także wchodzenie kultur w różnego rodzaju interakcje. Jest to: „zbiór zasad i procesów realizacji współżycia społecznego w warunkach realizacji pluralizmu etnicznego i kulturowego, nastawionych przy tym na optymalizację stosunków społecznych przez wyrównywanie praw i szans uczestnictwa, co pozwala na niwelację napięć i konfliktów"19.

\footnotetext{
${ }^{15}$ Leon DyCZEWSKI, „Tożsamość społeczno-kulturowa w globalizującym się świecie”, Kultura i Spoleczeństwo nr 1(2000): 27-28.

${ }^{16}$ Leon DYCZEWSKI, „Dialog kultur w perspektywie europejskiej”, w Polskość i symbioza kultur w integrującej się Europie, red. Jerzy Damrosz (Ciechanów: Krajowy Ośrodek Dokumentacji Regionalnych Towarzystw Kultury, 2000), 7.

${ }^{17}$ Tamże.

18 Tamże.

${ }^{19}$ Hanna MAMZER, Tożsamość w podróży. Wielokulturowość a ksztaltowanie tożsamości jednostki (Poznań: Wydawnictwo Naukowe UAM, 2003), 33.
} 
Po drugie, fenomen wielokulturowości opiera się na dwóch zasadniczych wartościach: wolności i równości. Wolność oznacza możliwość kultywowania wybranej kultury, równość to takie samo prawo kultur do istnienia i rozwoju. Nie mówimy zatem o jednoznacznej dominującej kulturze, nadrzędnej względem innych.

Po trzecie, przyjmuję trafny, choć być może nieco uproszczony, dychotomiczny podział na wielokulturowość etniczną i nieetniczną ${ }^{20}$ bądź, jak określił Stanley Fish, podział na multikulturalizm silny (strong multiculturalism) oraz multikulturalizm butikowy (boutique multiculturalism). „Pierwszy z nich domaga się głębokiego respektu dla wszystkich kultur, gdyż każda z nich ma prawo do tworzenia nie tylko własnej tożsamości zbiorowej, ale także do wyznaczania norm racjonalności i humanizmu" ${ }^{21}$. Jest to zatem identyfikacja oparta na cechach wynikających z dziedzictwa przeszłości i uznaniu podmiotowości wszystkich grup etnicznych zamieszkujących dane terytorium. Cechują ją także trwałe wielopłaszczyznowe i dobrowolne formy kontaktów międzykulturowych ${ }^{22}$. Istotne jest także zapewnienie przekazu międzypokoleniowego struktur i instytucji kulturowych konstytuujących fundament aksjonormatywny grupy ${ }^{23}$. Uzupełnieniem multikulturalizmu silnego jest multikulturalizm butikowy, charakteryzujący pobieżne czy kosmetyczne przywiązanie do przedmiotu tradycji odmiennej od innych ${ }^{24}$. To właśnie wizja wielokulturowości, którą Stanley Fish określa jako butikową, sprowadza się do prostego nasycenia przestrzeni społecznej symbolami identyfikującymi kulturowe zróżnicowanie, z których wiele zyskało status globalnych ${ }^{25}$. Chodzi tutaj o popularne restauracje etniczne, festiwale i imprezy, które w sposób nader prosty manifestują kulturową inność ${ }^{26}$. Jest to swoisty folkloryzm globalny, który coraz silniej kształtuje styl naszego życia. Dzisiaj, w każdym zakątku świata możemy skorzystać z sieci znanych światowych restauracji, skorzystać z ulubionego hotelu czy kupić buty znanej światowej marki. Produkty różnych

\footnotetext{
${ }^{20}$ Przyjmuję podział za: Janusz MuchA, „Wielokulturowość etniczna i nieetniczna”, Sprawy Narodowościowe nr 14-15(1999): 41-51.

${ }^{21}$ Stanley FisH, „Boutique Multiculturalism, or Why Liberale Are Incapable of Thinking about Hale Speech”, Critical Inquiry 23, nr 2(1997): s. 381, http://www.jstor.org/stable/1343988 (dostęp: 10.09.2019).

${ }^{22}$ ŚLIZ, SzCZEPAŃSKI, „Wielokulturowość i jej socjologiczny sens”, 9.

${ }^{23}$ Tamże, 19.

${ }^{24}$ Wojciech Jerzy BurszTa, Świat jako więzienie kultury. Pomyślenia (Warszawa: Państwowy Instytut Wydawniczy, 2008), 69; FISH, „Boutique Multiculturalism”, s. 378.

${ }^{25}$ ŚLIZ, SzCZEPAŃSKI, „Wielokulturowość i jej socjologiczny sens”, 9.

${ }^{26}$ FisH, ,Boutique Multiculturalism”, s. 378.
} 
kultur są dostępne wszędzie, a równocześnie koloryzują ulice światowych, europejskich i polskich miast.

\section{ROLA MEDIÓW LOKALNYCH \\ W UPOWSZECHNIANIU WIELOKULTUROWOŚCI}

W wielokulturowym świecie wciąż poszukiwane są skuteczne sposoby poznawania specyfiki i bogactwa innych kultur, mające na celu przezwyciężanie izolacji, stygmatyzacji i problemów tożsamościowych. Jednym z wariantów nieformalnej edukacji wielokulturowej jest koncepcja uczenia się wielokulturowości za pośrednictwem mediów. Media, poprzez swoją powszechność i siłę oddziaływania, stwarzają największe możliwości udziału społeczeństwa w kulturze, przekazują i utrwalają pozytywne wzorce zachowań. Jak zaznacza Małgorzata Gruchoła, w ramach swej kulturotwórczej roli - w myśl Strategii państwa polskiego w dziedzinie mediów elektronicznych na lata 2005-2020 - media powinny udostępniać osiągnięcia kultury, wyrabiając u odbiorców jej znajomość oraz podnosząc ich kompetencję kulturalną. Winny edukować i przygotowywać widza do świadomego odbioru dóbr „wysokiej kultury", umacniać tożsamość kulturową oraz budować więzi społeczne. Ponadto promować dorobek kulturalny, kreować wydarzenia kulturalne, pełnić rolę animatora kultury przez mecenat (sponsorowanie, udostępnianie anteny debiutantom) oraz produkcję lub koprodukcję dzieł kultury. Media, szczególnie publiczne, powinny promować polską kulturę poprzez udział w festiwalach i targach ${ }^{27}$. L. Dyczewski, obserwując rozwój nowych kanałów komunikowania, przepływ wiedzy i informacji, wprowadził do refleksji nad różnorodnymi systemami przekazu kultury pojęcie „domowej wielokulturowości medialnej" umożliwiającej styczność z odmiennymi kulturami za pomocą mediów, bez potrzeby przemieszczania się przestrzennego ${ }^{28}$. Wpisuje się ona w koncepcję doświadczeń zapośredniczonych Antony’ego Giddensa „[...] praktycznie całe ludzkie doświadczenie jest zapośredniczone przez język - a w kolejnych stanach rozwoju społecznego - media. Konsekwencją takiego założenia jest to, że z wieloma zjawiskami bezpośrednio człowiek

\footnotetext{
${ }^{27}$ Małgorzata GRUCHOŁA, „Kulturotwórcza rola mediów publicznych: upadek czy rozwój?”, w Wspótczesne media - kryzys w mediach?, t. 1, red. Iwona Hofman, Danuta Kępa-Figura (Lublin: Wydawnictwo UMCS, 2012), 39.

${ }^{28}$ Leon DyCZEWSKI, „Tożsamość w domowej wielokulturowości”, w Tożsamość w wielokulturowym kontekście, red. Leon Dyczewski, Krzysztof Jurek (Lublin-Warszawa: Centrum Europejskie Natolin-Wydawnictwo KUL, 2013), 275.
} 
styka się niezwykle rzadko (lub wręcz wcale), natomiast często doświadcza ich za pomocą innych przekaźników" ${ }^{29}$. Dostęp do zasobów treści, obrazów i dźwięków może stać się impulsem do kreowania świadomości i tożsamości otwartej na „inność”. Podstawą mechanizmu regulującego postawę otwartą lub zamkniętą jednostki na przekazywane treści o wielokulturowości w domu stanowią wartości. Społeczny odbiór tych treści przyczynia się do zrozumienia postaw innych, ich doświadczeń i przekonań. Dyczewski przewidywał, że „domowa wielokulturowość medialna” obok kontaktów bezpośrednich z ,innymi" stanie się podstawowym czynnikiem wzbogacającym, a także sprzyjającym pojawianiu się postaw ciekawości i tolerancji w procesie edukacji wielo- i międzykulturowej. Kontakt z inną kulturą poprzez media ma swoiste cechy: nie jest to kontakt całościowy, ale fragmentaryczny; brakuje mu szerokiego i całościowego kontekstu, bo często są eksponowane elementy atrakcyjne, a w cień spychane elementy mało przyciągające uwagę widza, a dla danej kultury ważne; jest to kontakt zapośredniczony, a tym samym odpersonalizowany, najczęściej zindywidualizowany, poszczególne jednostki są rozrzucone przestrzennie, nie wymieniają między sobą wrażeń i przeżyć towarzyszących styczności z odmienną kulturą ${ }^{30}$.

Media pełnią zatem ważną edukacyjną i kulturotwórczą funkcję w procesach upowszechniania wiedzy. Przyczynia się ona do lepszego poznania mniejszości etnicznych i narodowych oraz poszerza i wzbogaca konteksty rozumienia kultur wspólnot mniejszościowych. Warto w tym miejscu wskazać na funkcje mediów, dzięki którym oddziałują one na procesy integracyjne w różnych obszarach, m.in. politycznym, gospodarczym, społecznym i kulturalnym. Należą do nich przede wszystkim funkcja poznawczo-kształcąca (źródło informacji), emocjonalno-motywacyjna (oddziaływanie na sferę motywacyjną), działaniowo-interakcyjna (wzajemne komunikowanie się, prowadzenie dyskursu opartego na dialogu).

Rola lokalnych środków społecznego komunikowania w przybliżaniu problematyki i zagadnień wielokulturowości wynika z co najmniej kilku powodów ${ }^{31}$ :

- Media lokalne są podstawą funkcjonowania demokracji na szczeblu lokalnym i są jednym z instrumentów realizacji zasady podmiotowości obywatelskiej oraz przestrzegania prawa, mogą zatem przypominać o podmiotowości

\footnotetext{
${ }^{29}$ Anthony Giddens, Nowoczesność i tożsamość. „Ja” i społeczeństwo późnej nowoczesności (Warszawa: Wydawnictwo Naukowe PWN, 2001), 33-39.

${ }^{30}$ Tamże, 278.

${ }^{31}$ Szerzej: Stanisław MichaLCZYK, „Media lokalne w komunikacji społecznej. Aktualne potrzeby badawcze", w Regionalne i lokalne media w spoleczeństwie wielokulturowym, red. Joachim Glensk, Maria Kalczyńska (Opole: Wydawnictwo Uniwersytetu Opolskiego, 2004), 15-16.
} 
wszystkich grup etnicznych i mniejszościowych zamieszkujących dane środowisko lokalne.

- Media lokale mają możliwości zapobiegania nie tyle globalizacji, co raczej uniwersalizacji w znaczeniu rozmywania się lokalnych i regionalnych wartości oraz norm społecznych.

- Media lokalne należy traktować jako zasoby materialne społeczności lokalnej i regionalnej, koncentrujące wokół siebie zasoby intelektualne, a to połączenie stanowi przesłankę lokalnych procesów rozwojowych, czynnik zmian społecznych i ich dynamiki oraz porządkowania przestrzeni tradycyjnych społeczności - mogą zatem przybliżać jakościowo nowe, kulturowo zróżnicowane lokalności.

Z pewnością media lokalne mogą przyczyniać się do rozumienia i kształtowania postawy szacunku w odniesieniu do wielokulturowości i mogą to czynić na wiele sposobów. Trzy z nich są szczególnie praktyczne i warte wyeksponowania:

1. Wąskie upowszechnianie zagadnień wielokulturowości polegające na skupianiu uwagi na wydarzeniach lokalnych, współpracy szkół, placówek i osób - liderów i animatorów lokalnych, na eksponowaniu afirmowania różnorodności kulturowej na terenie danego regionu.

2. Szerokie upowszechnianie wielokulturowości polegające na przekraczaniu granic własnego regionu, translokalna współpraca i szeroka, pogłębiona edukacja wielokulturowa ${ }^{32}$.

3. Informowanie o różnorodności w sposób rzetelny, pogłębiony, dokładny i empatyczny jako wyznacznik odpowiedzialnego (inkluzywnego) dziennikarstwa, w którym chodzi o podmiotowe traktowanie wszystkich członków społeczeństwa, ma zasadnicze znaczenie dla rozwiązywania ukrytych lub otwartych konfliktów między społecznością dominującą i mniejszościami, jest narzędziem budowania dialogu i pokojowych kroków ${ }^{33}$.

\footnotetext{
${ }^{32}$ Agnieszka RogALSKA, „Lokalna telewizja kablowa szansa otwierania się na wielokulturowość w dobie integracji europejskiej”, w: Regionalne i lokalne media w spoleczeństwie wielokulturowym, red. Joachim Glensk, Maria Kalczyńska (Opole: Wydawnictwo Uniwersytetu Opolskiego, 2004), 145.

${ }^{33}$ Milica PESIC, „Rola mediów w informowaniu o różnorodności”, w Multikulturalizm w świecie mediów, red. Magdalena Ratajczak (Wrocław: Wydawnictwo UWr, 2007), 154.
} 


\section{MEDIALNE KREACJE WIELOKULTUROWOŚCI \\ - STRUKTURY PÓL SEMANTYCZNYCH \\ WOKÓŁ POJĘCIA „WIELOKULTUROWY LUBLIN”}

W analizach własnych zastosowano technikę analizy pól semantycznych w ujęciu Regine Robin. W latach 80. XX wieku Robin przedstawiła teoretyczne podstawy pól znaczeniowych i opracowała własną wersję metody analizy pól semantycznych. Wyszła z założenia, że tekst nie jest przezroczysty szukanie znaczenia tekstu, zdania, wyrazu wymaga pewnej pracy nad tekstem, pozornego rozłożenia ciągu wypowiedzeniowego i porządku wypowiedzi po to, by złożyć je na powrót zgodnie z czytelnością znaczącą ${ }^{34}$. Kolejnym ustaleniem Robin jest twierdzenie, że leksyki (czyli zasoby słów danego języka) „nie są zwykłym zlepkiem pewnej liczby izolowanych wyrazów, to system, w którym wszystkie jednostki są ze sobą skoordynowane lub przeciwstawione"35. Strukturę każdej leksyki można opisać za pomocą siatek relacji. Robin wymienia kilka takich siatek: opozycje, asocjacje, elementy utożsamiane ekwiwalenty przybliżone, określenia, czyny podmiotu lub wykonawca czynności („funkcja czyjaś” - działanie wykonywane przez podmiot, „funkcja na” - działania skierowane na podmiot przez inne siły) ${ }^{36}$. W analizie własnej wykorzystane zostaną tylko niektóre siatki relacji.

Tabela nr 1. Tabela siatek relacji pola semantycznego tekstów dzienników Kurier Lubelski i Dziennik Wschodni

\begin{tabular}{||c|c|c||}
\hline $\begin{array}{c}\text { Typ relacji } \\
\text { - siatki } \\
\text { semantyczne }\end{array}$ & $\begin{array}{c}\text { Elementy pola semantycznego } \\
\text { wokól pojęcia } \\
\text { "wielokulturowy Lublin” } \\
\text { Kurier Lubelski }\end{array}$ & $\begin{array}{c}\text { Elementy pola semantycznego } \\
\text { wokól pojęcia }\end{array}$ \\
określenia & $\begin{array}{l}\text { histokulturowy Lublin" } \\
\text { Dziennik Wschodni }\end{array}$ \\
\hline $\begin{array}{l}\text { na jest z obecnością mniejszości } \\
\text { narodowych i religijnych, oparta na }\end{array}$ & $\begin{array}{l}\text { kontakt z innymi kulturami był nieco- } \\
\text { dzienną okazją do zapoznania się } \\
\text { z ich obyczajami, tradycjami i wiarą; }\end{array}$ \\
\hline
\end{tabular}

\footnotetext{
${ }^{34}$ Regine RoBIN, „Badanie pól semantycznych. Doświadczenia Ośrodka Leksykologii Politycznej w Saint-Cloud”, w Język i społeczeństwo, red. Michał Głowiński (Warszawa: Czytelnik 1980), 252.

35 Tamże.

${ }^{36}$ Opozycje to wyrażenia określające przeciwstawienia do obiektu badań; asocjacje to powiązania skojarzenia i elementy z otoczenia podmiotu o charakterze kontekstowym; ekwiwalenty to substytuty semantyczne, wyrażenia, które mogą zastępować obiekt badania, wskazują więc pojęcia z nim tożsame; określenia - epitety, wyrażenia charakteryzujące obiekt badań, określające jego istotę lub sposób bycia; działania podmiotu to aktywności wraz ze skutkami samego obiektu badań, jak i jego otoczenia. Szczegółowa charakterystyka i opis poszczególnych siatek: tamże, s. 253-255.
} 


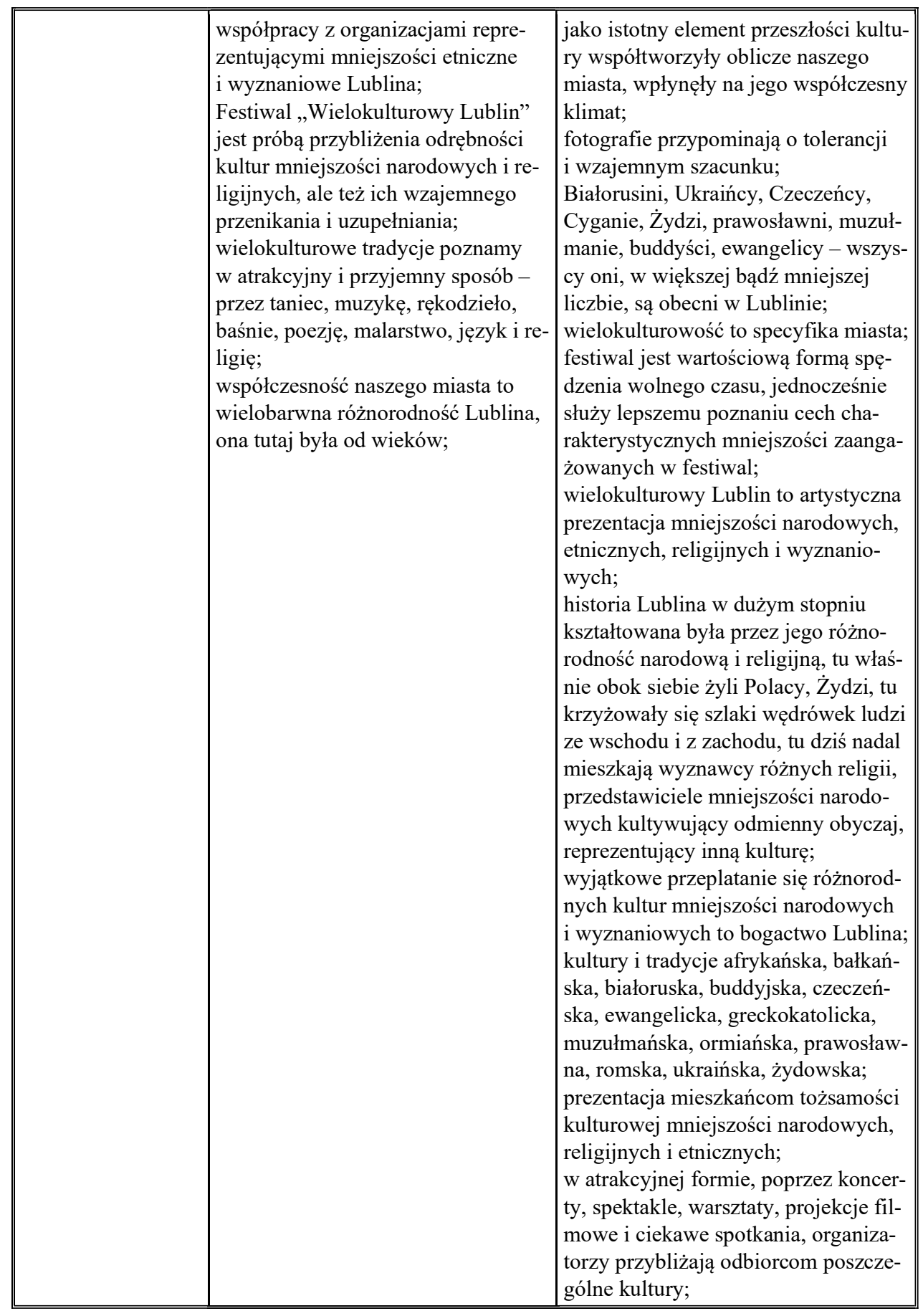




\begin{tabular}{|c|c|c|}
\hline ekwiwalenty & miasto różnych mniejszości; & $\begin{array}{l}\text { miasto przeplatania się różnorodnych } \\
\text { kultur mniejszości narodowych i wy- } \\
\text { znaniowych; }\end{array}$ \\
\hline asocjacje & $\begin{array}{l}\text { poznajmy się nawzajem; } \\
\text { mieszkańcy Lublina - przedstawi- } \\
\text { ciele różnych mniejszości naro- } \\
\text { dowych, etnicznych, religijnych } \\
\text { i wyznaniowych, są wśród nich np. } \\
\text { buddyści czy reprezentanci kultur } \\
\text { afrykańskich; }\end{array}$ & $\begin{array}{l}\text { wzajemne poznawanie się, tworzenie } \\
\text { jednej całości; } \\
\text { spotkania poprzez działania edukacyj- } \\
\text { ne i artystyczne promują tolerancję } \\
\text { i dialog międzykulturowy; } \\
\text { Lublin od wieków związany jest } \\
\text { z obecnością mniejszości narodowych } \\
\text { i religijnych; } \\
\text { Lublin wielokulturowy, dzięki czemu } \\
\text { bogatszy; } \\
\text { różnorodne formy prezentacji artys- } \\
\text { tycznej o charakterze edukacyjnym; } \\
\text { festiwal zaowocuje poprawą jakości } \\
\text { więzi społecznych i przełamaniem } \\
\text { wzajemnych stereotypów; }\end{array}$ \\
\hline opozycje & $\begin{array}{l}\text { mieszkańcom Lubelszczyzny naj- } \\
\text { trudniej zaakceptować w otoczeniu } \\
\text { osoby chore psychicznie, homosek- } \\
\text { sualnych mężczyzn i Romów; } \\
\text { Lublin na co dzień wydaje się mono- } \\
\text { litem; } \\
\text { droga, która zaczyna się od niewie- } \\
\text { dzy i biegnie przez stereotyp, kończy } \\
\text { się z reguły na nienawiści; }\end{array}$ & \\
\hline
\end{tabular}

Źródło: opracowanie własne

Tabela nr 2. Tabela siatek relacji pola semantycznego tekstów tygodników Nowy Tydzień i Nasze Miasto

\begin{tabular}{|c|l|l||}
\hline Typ relacji & $\begin{array}{c}\text { Elementy pola semantycznego } \\
\text { wokól pojęcia } \\
\text { "wielokulturowy Lublin" } \\
\text { Nowy Tydzień }\end{array}$ & $\begin{array}{c}\text { Elementy pola semantycznego } \\
\text { wokól pojęcia } \\
\text { "wielokulturowy Lublin" } \\
\text { Nasze Miasto }\end{array}$ \\
\hline określenia & $\begin{array}{l}\text { dziedzictwo Unii Lubelskiej jako } \\
\text { inspiracji do integracji europejskiej; } \\
\text { ten projekt w sposób muzyczno-obra- } \\
\text { zowy mówi o żywej wielokulturowo- } \\
\text { ści Lublina; } \\
\text { za najbardziej wielokulturowy i nieza- } \\
\text { leżny uznaje twórczyni teatroterapii }\end{array}$ & $\begin{array}{l}\text { miasto, w którym mieszkali i miesz- } \\
\text { kają przedstawiciele różnych kultur; }\end{array}$ \\
\hline
\end{tabular}




\begin{tabular}{|c|c|c|}
\hline & $\begin{array}{l}\text { w Lublinie fenomen teatru, jeśli pozo- } \\
\text { stanie wolny od wpływu polityki; } \\
\text { Lublin jest na drugim miejscu w Pol- } \\
\text { sce pod względem liczby studentów } \\
\text { zagranicznych; }\end{array}$ & \\
\hline ekwiwalenty & $\begin{array}{l}\text { miasto różnych kultur, różnych religii, } \\
\text { różnych ateizmów; }\end{array}$ & miasto przedstawicieli różnych kultur; \\
\hline asocjacje & $\begin{array}{l}\text { bogactwo kultur i tradycji mniejszości } \\
\text { narodowych i religijnych w Lublinie; } \\
\text { przełamanie stereotypów i promowa- } \\
\text { nie tolerancji; } \\
\text { miasto wyjątkowe z wielokulturową } \\
\text { historią; } \\
\text { wystawy, koncerty, projekcje filmów, } \\
\text { spektakle i zwiedzanie miasta śladami } \\
\text { różnych kultur, będzie radośnie, ko- } \\
\text { lorowo, każdy znajdzie coś dla siebie; } \\
\text { cudzoziemcy, którzy dobrze będą się } \\
\text { tu czuli, staną się rzecznikami nasze- } \\
\text { go miasta; }\end{array}$ & $\begin{array}{l}\text { cel wydarzenia to przede wszystkim } \\
\text { przełamanie stereotypów i promowa- } \\
\text { nie tolerancji; } \\
\text { koncerty, wykłady, spotkania, } \\
\text { warsztaty; } \\
\text { wystawy, projekcje filmów, występy } \\
\text { zespołów ludowych oraz panele dys- } \\
\text { kusyjne składają się na bogaty pro- } \\
\text { gram Dni Kultury Bałkańskiej w Lu- } \\
\text { blinie; } \\
\text { symboliczny gest wypuszczenia } \\
\text { gołębi; }\end{array}$ \\
\hline opozycje & $\begin{array}{l}\text { ataki na cudzoziemców; } \\
\text { policja odnotowała } 21 \text { przestępstw na } \\
\text { tle nienawiści rasowej, etnicznej i wy- } \\
\text { znaniowej; } \\
\text { Lublin przestaje być miastem przyjaz- } \\
\text { nym; } \\
\text { lata zaniedbań, lata milczącego przy- } \\
\text { zwolenia na nienawiść, atmosferę } \\
\text { przyzwolenia dla czynnej agresji } \\
\text { wobec tzw. innych, kogoś z zewnątrz; } \\
\text { nasze środowisko odchodzi od tole- } \\
\text { rancji wobec inności wokół nas, } \\
\text { w kierunku ksenofobii; } \\
\text { mit ,jednolitego etnicznie Lublina” } \\
\text { oraz rzekomego konfliktu cywilizacji; }\end{array}$ & $\begin{array}{l}\text { nie ma tu miejsca na inny kolor skóry, } \\
\text { narodowość, także na inne poglądy, } \\
\text { np. lewaków w tym kraju; }\end{array}$ \\
\hline
\end{tabular}

Źródło: opracowanie własne

Jakościowa analiza zawartości materiału prasowego pozwoliła na wyszczególnienie kategorii tematycznie łączących się z wielokulturowością Lublina. Wokół zagadnień szczegółowych dają się wykreślić pola semantyczne złożone z wyrażeń opisujących badane zjawiska. Wśród kategorii tematycznych do najważniejszych zaliczyć można następujące: 
- Dostrzeganie w przestrzeni miejskiej Lublina obecności reprezentantów różnych narodowości, kultur, religii - są nimi Ukraińcy, Białorusini, Czeczeńcy, Cyganie, Żydzi, prawosławni, muzułmanie, buddyści, ewangelicy. Treści publikacji nawiązują do przeszłości - do miejsc, gdzie obok siebie żyli Polacy, Żydzi, do miejsc, gdzie krzyżowały się szlaki wędrówek ludzi ze wschodu i z zachodu, oraz współczesności - miasta, gdzie dziś nadal mieszkają wyznawcy różnych religii, przedstawiciele mniejszości narodowych kultywujący odmienne obyczaje, reprezentujący inne kultury.

- Informowanie o różnorodnych wydarzeniach związanych $z$ wielokulturowością Lublina, których celem jest promocja innych kultur oraz integracja międzykulturowa - siatki znaczeniowe akcentują różnorodność kultur i tradycji - wymieniane są kultury ponadnarodowe, narodowe i religijne takie, jak: afrykańska, bałkańska, białoruska, buddyjska, czeczeńska, ewangelicka, greckokatolicka, muzułmańska, ormiańska, prawosławna, romska, ukraińska i żydowska, opisywane są także formy ich wyrażania poprzez koncerty, spektakle, warsztaty, taniec, śpiew, projekcje filmowe i ciekawe spotkania.

- Podzial na wielokulturowość historyczną (silną) i współczesną (słabą - tzw. butikową) - w polach semantycznych odnajdziemy nawiązanie do dziedzictwa Unii Lubelskiej jako inspiracji do integracji europejskiej i powtarzane jednakowe treści, że historia Lublina od wieków związana jest z obecnością mniejszości narodowych i religijnych, co w sposób szczególny wpływa na oblicze miasta i jest istotną częścią lubelskiego krajobrazu kulturalnego. Festiwal „Wielokulturowy Lublin” jest nie tylko próbą przybliżenia odrębności kultur mniejszości narodowych i religijnych, ale też ich wzajemnego przenikania i uzupełniania.

- Przejawy tworzenia się nowego wielokulturowego społeczeństwa z przewagą elementów świadczących o słabej „butikowej” wielokulturowości - pola semantyczne opierają się głównie na wyrażeniach konotujących treści o różnorodności wydarzeń prezentujących wydarzenia i imprezy kulturalne, wyraźnie brakuje treści o stopniu instytucjonalizacji grup mniejszościowych.

- Przykłady kultywowania tradycji i zwyczajów grup zróżnicowanych kulturowo, religijnie i narodowościowo, aktywne uczestnictwo w świętach i wydarzeniach propagujących wlasną kulturę - pola semantyczne dostarczają treści o wielokulturowych tradycjach, poznawanych w atrakcyjny i przyjemny sposób, np. przez taniec, muzykę, rękodzieło, baśnie, poezję, malarstwo, język i religię. 
- Negatywne zjawiska towarzyszące wielokulturowości - w strukturze pól semantycznych odnajdziemy treści o atakach na cudzoziemców na tle nienawiści rasowej, etnicznej i wyznaniowej, pojawiają się określenia, że Lublin przestaje być miastem przyjaznym, bowiem obecne jest przyzwolenie dla nienawiści i dla czynnej agresji wobec innych.

- Marketingowy i turystyczny wymiar wielokulturowości - w polach znaczeniowych znalazły się wskazania, że Lublin jest na drugim miejscu w Polsce pod względem liczby studentów zagranicznych, a cudzoziemcy, którzy dobrze będą się tu czuli, staną się najlepszymi rzecznikami naszego miasta.

\section{ZAKOŃCZENIE}

Lublin obok Wrocławia, Białegostoku i Gdańska należy do grupy najbardziej wielokulturowych miast Polski. Od wieków ścierały się tu kultury Wschodu i Zachodu, przenikając kultury lokalne i regionalne. Jak zapisano w Strategii Rozwoju Lublina, celem polityki miejskiej jest „wzmacnianie otwartości kulturowej” ${ }^{37}$. Zasadniczy problem towarzyszący przedmiotowym refleksjom w artykule dotyczył pytania o jakość prasowego dyskursu o wielokulturowości. Czy przyczynia się on do jakościowych, pozytywnych zmian w sferze społecznej, ekonomicznej, lokalnej bądź środowiskowej i czy w konsekwencji prowadzi do budowania społeczeństw opartych na humanistycznych wartościach w pełni demokratycznych. W szczególności interesowały mnie dwa zagadnienia: środki językowe tworzenia dyskursu o wielokulturowości oraz tematyczne kategorie definiujące wielokulturowość miejsca. Wskazują one na różne konteksty prasowego wizerunku wielokulturowego Lublina. Podkreślić należy, że Lublin w prasie lokalnej ukazywany jest jako miejscowość o bogatej historii i dziedzictwie różnych kultur. Lokalni dziennikarze budują pozytywny wizerunek wielokulturowego miasta, jednakże ich dziennikarski warsztat nie jest zbyt atrakcyjny i urozmaicony. Brakuje wyznaczników odpowiedzialnego, tzw. inkluzywnego dziennikarstwa: opracowań pogłębionych, szczegółowych i popartych wyczerpującymi analizami. Nie znajdziemy też informacji o instytucjonalizacji innych grup i wchodzeniu kultur mniejszościowych we wzajemne interakcje. Dzięki nim najpełniej wyrażałoby się podmiotowe traktowanie wszystkich mieszkańców. Poczucie

${ }^{37}$ Strategia rozwoju Lublina, http://strategia2020.lublin.eu/wp-content/uploads/2016/09/StrategiaRozwoju-Lublina-na-lata-2013-2020-wyd.II_.pdf (dostęp: 25.11.2019). 
podmiotowości ma niewątpliwie zasadnicze znaczenie dla rozwiązywania ukrytych lub otwartych konfliktów między społecznością dominującą i mniejszościami, jest narzędziem budowania dialogu i pokojowych rozwiązań. Bogate i różnorodne kategorie tematyczne dyskursu o wielokulturowości Lublina z pewnością przyczyniają się do bardziej świadomego i pełniejszego rozumienia, a także akceptowania różnorodności kultur mniejszościowych. Kształtując kategorię wielokulturowości, należy nieco intensywniej nasycać ją treściami aksjologicznymi ${ }^{38}$, aby wyraźnie wskazywała na dynamikę wzajemności w relacjach między odmiennymi światami wartości, w których za wszelką cenę należy poszukiwać tego, co wspólne.

\section{BIBLIOGRAFIA}

BuRNET, Jean. „Multiculturalism, Immigration and Racism”. Canadian Ethnic Studies 7, nr 1(1975): 35-39.

BurszTA, Wojciech Józef. Świat jako więzienie kultury. Pomyślenia. Warszawa: Państwowy Instytut Wydawniczy, 2008.

DyCZEwSKI, Leon. „Tożsamość w domowej wielokulturowości”. W Tożsamość w wielokulturowym kontekście, redakcja Leon Dyczewski, Krzysztof Jurek, 275-283. Lublin-Warszawa: Centrum Europejskie Natolin-Wydawnictwo KUL, 2013.

DycZEwsKI, Leon. Kultura $w$ całościowym planie rozwoju. Warszawa: Instytut Wydawniczy Pax, 2011.

DyCZEwski, Leon. „Dialog kultur w perspektywie europejskiej”. W Polskość i symbioza kultur w integrujacej się Europie, redakcja Jerzy Damrosz, 7-21. Ciechanów: Krajowy Ośrodek Dokumentacji Regionalnych Towarzystw Kultury, 2000.

DYCZEWSKI, Leon. „Tożsamość społeczno-kulturowa w globalizującym się świecie”. Kultura i Spoleczeństwo $\mathrm{nr}$ 1(2000): 27-42.

EAGLETon, Terry. Iluzje postmodernizmu. Tłumaczył Piotr Rymarczyk. Warszawa: Wydawnictwo Spacja, 1998.

FISH, Stanley. „Boutique Multiculturalism, or Why Liberale Are Incapable of Thinking about Hale Speech". Critical Inquiry 23, nr 2(1997): 378-395. http://www.jstor.org/stable/1343988 (dostęp: 10.09.2019).

GidDENS, Anthony. Nowoczesność i tożsamość. „Ja” i spoleczeństwo późnej nowoczesności. Warszawa: Wydawnictwo Naukowe PWN, 2001.

Glazer, Nathan. We Are All Multiculturalists Now. Cambridge (MA): Harvard University Press, 1997.

${ }^{38}$ Zob. Marek RemBIERZ, „Edukacja międzykulturowa jako ćwiczenie duchowe. Pedagogika wymiany kształtowania kultury duchowej i rozumienia wartości ponadkulturowych w kontekście zróżnicowania religijnego i pluralizmu światopoglądowego", Edukacja międzykulturowa nr 2(9) (2018): 95. 
GRUCHOŁA, Małgorzata. „Kulturotwórcza rola mediów publicznych: upadek czy rozwój?”. W Wspótczesne media - kryzys w mediach? Tom 1, redakcja Iwona Hofman, Danuta Kępa-Figura, 33-56. Lublin: Wydawnictwo UMCS, 2012.

GolKA, Marian. Socjologia kultury. Warszawa: Scholar, 2007.

Kolodir, Antonina. „The Idea and Diverse Reality of Multiculturalism: Are They Applicable to Newly Independent States?”. Political Studies, https://political-studies.com/?p=734\&lang=en (dostęp: 10.09.2019).

KyMLICKA, Will. Multicultural Citizenship: A Liberal Theory of Minority Rights. Oxford: Clarendon Press, 1995.

LAвоснA, Janina. Tekst, wypowiedź, dyskurs w procesie komunikacji językowej. Kraków: Wydawnictwo UJ, 2008.

LyotARD, Jean-Francois. „Beantwortung der Frage: Was ist postmodern?”. W TENŻE, Postmoderne für Kinder. Briefwechsel aus den Jahren 1982-1985, 11-31. Wiedeń: Passagen Verlag, 1987.

MAĆKIEWICZ, Jolanta. „Wyspa - językowy obraz wycinka rzeczywistości”. W Językowy obraz świata, redakcja Jerzy Bartmiński, 193-206. Lublin: Wydawnictwo UMCS, 1999.

MAMZer, Hanna. Tożsamość w podróży. Wielokulturowość a kształtowanie tożsamości jednostki. Poznań: Wydawnictwo Naukowe UAM, 2003.

MichALCZYK, Stanisław. „Media lokalne w komunikacji społecznej. Aktualne potrzeby badawcze”. W Regionalne i lokalne media w spoleczeństwie wielokulturowym, redakcja Joachim Glensk i Maria Kalczyńska, 15-25. Opole: Wydawnictwo Uniwersytetu Opolskiego, 2004.

MiKUŁOWSKI-POMORSKI, Jerzy. „Współczesny problem kulturowości i wielokulturowości w komunikowaniu". W Multikulturalizm w sferze mediów, redakcja Magdalena Ratajczak, 13-42. Wrocław: Wydawnictwo UWr, 2007.

MuchA, Janusz. „Wielokulturowość etniczna i nieetniczna”. Sprawy Narodowościowe nr 1415(1999): 41-51.

PESIC, Milica. „Rola mediów w informowaniu o różnorodności”. W Multikulturalizm $w$ świecie mediów, redakcja Magdalena Ratajczak, 147-155. Wrocław: Wydawnictwo Uniwersytetu Wrocławskiego, 2007.

REMBIERZ, Marek. „Otwarcie edukacji międzykulturowej na krytyczną recepcję pedagogicznego przesłania religii w kontekście pluralizmu światopoglądowego". Społeczeństwo. Studia, prace badawcze i dokumenty z zakresu nauki społecznej Kościoła nr 3(142)(2018): 26-74.

REMBIERZ, Marek. „Edukacja międzykulturowa jako ćwiczenie duchowe. Pedagogika wymiany kształtowania kultury duchowej i rozumienia wartości ponadkulturowych w kontekście zróżnicowania religijnego i pluralizmu światopoglądowego". Edukacja międzykulturowa nr 2(9) (2018): 90-130.

RoBIN, Regine. „Badanie pól semantycznych. Doświadczenia Ośrodka Leksykologii Politycznej w Saint-Cloud”. W Język i społeczeństwo, redakcja Michał Głowiński, 252-281. Warszawa: Czytelnik, 1980.

RogalsKa, Agnieszka. „Lokalna telewizja kablowa szansa otwierania się na wielokulturowość w dobie integracji europejskiej”. W Regionalne i lokalne media w społeczeństwie wielokulturowym, redakcja Joachim Glensk i Maria Kalczyńska, 135-149. Opole: Wydawnictwo Uniwersytetu Opolskiego, 2004.

Strategia rozwoju Lublina, http://strategia2020.lublin.eu/wp-content/uploads/2016/09/StrategiaRozwoju-Lublina-na-lata-2013-2020-wyd.II_.pdf (dostęp: 25.11.2019). 
Szulich-Katuża, Justyna. Projekty tożsamościowe rodziny upowszechniane $w$ polskich tygodnikach opiniotwórczych. Lublin: Wydawnictwo KUL, 2013.

ŚLIZ Anna i Marek Stanisław SzcZEPAŃSKI. „Wielokulturowość i jej socjologiczny sens. Festival Caravan czy Wielokulturowe Street Party?”Studia Socjologiczne nr 4(2011): 7-25.

Welsch, Wolfgang. Nasza postmodernistyczna moderna. Tłumaczyli Roman Kubicki, Anna Zeidler-Janiszewska. Warszawa: Oficyna Naukowa, 1998.

Wykaz artykułów wykorzystanych w analizie własnej w układzie chronologicznym:

\section{Kurier Lubelski}

1. KowalczYK, Andrzej. „Festiwal Wielokulturowy Lublin 2011”. 23.05.2011, https://kurier lubelski.pl/festiwal-wielokulturowy-lublin-2011-koncerty-spektakle-wystawy/ar/406862.

2. FranCZAK, Paweł. „Buddyjski śpiew i żydowski taniec”. 27.05.2011, https://kurierlubelski.p1/ buddyjski-spiew-i-zydowski-taniec-wielokulturowy-lublin-program-wideo/ar/408595.

3. HeJno, Sylwia. „Wielokulturowy Lublin: Chałwa i swahili dla każdego (Program)”. 23.05.2012, https://kurierlubelski.pl/wielokulturowy-lublin-chalwa-i-swahili-dla-kazdego-program/ar/580583.

4. „Wielokulturowy Lublin 2013: 'Bądźmy jak kolorowy obraz””. 21.05.2013, https://kurier lubelski. pl/wielokulturowy-lublin-2013-badzmy-jak-kolorowy-obraz-program/ar/899668.

5. SH. „Miasto jak mozaika. Wielokulturowy Lublin 2014 (PROGRAM)”. 19.05.2014, https:// kurier lubelski.pl/miasto-jak-mozaika-wielokulturowy-lublin-2014-program/ar/3439831.

\section{Dziennik Wschodni}

6. WysockA, Marta. „Wielokulturowy Lublin”. 25.09.2008, https://www.dziennikwschodni.pl /co-gdzie-kiedy/wystawy/wielokulturowy-lublin,n,1000079233.html.

7. SZYMCZYK, Jacek. „Trzecia edycja festiwalu Wielokulturowy Lublin”. 26.09.2010, https:// www.dziennikwschodni.pl/co-gdzie-kiedy/inne/trzecia-edycja-festiwalu-wielokulturowy-lu blin,n,1000111820.html.

8. Wielosiewicz, Maria. „Lublin Wielokulturowy 2012 (program)”. 24.05.2012, https://www. dziennikwschodni.pl/co-gdzie-kiedy/festiwale/lublin-wielokulturowy-2012-program,n,1000 150332.html.

9. „Wielokulturowy Lublin 2013 (program)”. Opracowała redakcja. 20.05.2013, https://www. dziennikwschodni.pl/co-gdzie-kiedy/festiwale/wielokulturowy-lublin-2013-program,n,100000 8633.html.

10. Кмо. „Wielokulturowy Lublin 2014. Posłuchaj, posmakuj, poznaj (program)”. 21.05.2014, https://www.dziennikwschodni.pl/co-gdzie-kiedy/festiwale/wielokulturowy-lublin-2014-posluchaj -posmakuj-poznaj-program,n,140529936.html.

11. DRABIK, Damian. „Wielokulturowy Lublin 2016 (program)”. 25.05.2016, https://www. dziennik wschodni.pl/co-gdzie-kiedy/festiwale/wielokulturowy-lublin-2016-program,n,100 0181021.html.

12. DRABIK, Damian. „10. edycja Festiwalu Wielokulturowy Lublin”. 22.05.2017, https://www. dziennikwschodni.pl/co-gdzie-kiedy/festiwale/10-edycja-festiwalu-wielokulturowy-lublin,n, 100 0199635.html.

13. DRABIK, Damian. „Wielokulturowy Lublin 2018 - festiwal tradycji mniejszości (program)”. 14.05.2018, https://www.dziennikwschodni.pl/co-gdzie-kiedy/festiwale/wielokulturowy-lublin -2018-festiwal-tradycji-mniejszosci-program,n,1000218647.html. 
14. DRABIK, Damian. „Autobusem przez kulturę. Zapisy na 12. edycję Wielokulturowego Lublina!” 17.05.2019, https://www.dziennikwschodni.pl/co-gdzie-kiedy/festiwale/autobusem-przez -kulture-zapisy-na-12-edycje-wielokulturowego-lublina,n,1000242913.html.

Nowy Tydzień

15. KALwiŃSKA Emilia. „Lublin faszyzuje?” 2.03.2017, https://www.nowytydzien.pl/lublinfaszyzuje/.

16. „Lublin zaprasza na wielką majówkę”. Opracowała redakcja. 27.04.2017, https://www. nowytydzien.pl/lublin-zaprasza-wielka-majowke/.

17. RyвOŁowicz, Marek. „Czy grozi nam neochłopstwo”. 28.06.2017, https://www.nowy tydzien.pl/grozi-nam-neochlopstwo/.

18. RYвоŁOwiCZ, Marek. „Stop ksenofobii, dość nienawiści”. 7.09.2017, https://www.nowy tydzien.pl/stop-ksenofobii-dosc-nienawisci/.

19. NiEĆKо, Joanna. „Wielokulturowy Lublin”. 24.05.2018, https://www.nowytydzien.pl /wielokulturowy-lublin/.

Nasze Miasto

20. JASIŃSKA, Anna. „Pięć dni kulturowego kalejdoskopu w Lublinie”. 27.09.2009, https:// lublin.naszemiasto.pl/piec-dni-kulturowego-kalejdoskopu-w-lublinie/ar/c13-2957986.

21. „Wielokulturowy Lublin trafi na ekran”. Opracowała redakcja. 28.05.2009, https://lublin. naszemiasto.pl/wielokulturowy-lublin-trafi-na-ekran/ar/c13-2957944.

22. „Lublin mniej znany, Lublin wielu kultur”. Opracowała redakcja. 29.05.2017, https://lublin. naszemiasto.pl/lublin-mniej-znany-lublin-wielu-kultur/ar/c13-4132248.

23. „Wielokulturowy Lublin trafi na ekran”. Opracowała redakcja. 28.05.2009, https://lublin. naszemiasto.pl/wielokulturowy-lublin-trafi-na-ekran/ar/c13-2957944.

24. „Żacy spacerują po Lublinie”. Opracowała redakcja. 5.10.2009, https://lublin.naszemiasto.pl /zacy-spaceruja-po-lublinie/ar/c13-2954092.

\section{DYSKURS O WIELOKULTUROWOŚCI LUBLINA W LOKALNEJ PRASIE}

\section{Streszczenie}

Zasadniczym celem podjętym w artykule jest charakterystyka medialnego dyskursu o wielokulturowości w mediach lokalnych i pytanie, czy dyskurs przyczynia się do jakościowych, pozytywnych zmian w sferze społecznej, ekonomicznej, środowiskowej i budowania społeczeństw opartych na wartościach w pełni demokratycznych. W szczególności interesują mnie dwa zagadnienia: środki językowe w tworzeniu dyskursu o wielokulturowości oraz kategorie tematyczne i znaczeniowe definiujące wielokulturowość Lublina. Materiał badawczy tworzą artykuły prasowe lokalnych tytułów: internetowe wydania dzienników Kurier Lubelski i Dziennik Wschodni oraz bezpłatnych tygodników lubelskich: Nowy Tydzień i Nasze Miasto. W analizach własnych wykorzystane zostały: analiza zawartości i analiza pól semantycznych.

Słowa kluczowe: wielokulturowość; prasa lokalna; dyskurs medialny; wielokulturowy Lublin. 


\section{DISCOURSE ON THE MULTICULTURALISM OF LUBLIN IN THE LOCAL PRESS}

\section{Summary}

The main purpose of the article is to examine the media discourse on multiculturalism in local media and the question whether the discourse contributes to qualitative, positive changes in the social, economic and environmental spheres and whether it shapes the societies based on fully democratic values. In particular, I am interested in two issues: language measures in creating a discourse on multiculturalism and thematic and meaning categories defining multiculturalism in Lublin. The research material consists of press articles of local titles: online editions of the dailies: Kurier Lubelski and Dziennik Wschodni and free Lublin weeklies: Nowy Tydzień and Nasze Miasto. In our own analyses they were used: content analysis and analysis of semantic fields.

Key words: multiculturalism; local press; media discourse; multicultural Lublin. 